\title{
ASPEK PSIKOLOGI PEMBELAJARAN DARING MASA PANDEMI COVID-19 DENGAN CAPAIAN INDEKS PRESTASI KUMULATIF MAHASISWA VOKASI
}

\section{PSYCHOLOGICAL ASPECTS OF ONLINE LEARNING WITH THE VOCATIONAL STUDENT'S GRADE POINT AVERAGE}

\author{
Nurul Laili \\ Prodi D3 Keperawatan \\ STIKES Karya Husada Kediri \\ Korespondensi Penulis : nurullaili230279@gmail.com
}

\begin{abstract}
Abstrak
Perubahan yang terjadi dalam proses pembelajaran karena adanya pandemi, berdampak pada aspek psikologi mahasiswa. Faktor yang mempengaruhi aspek psikologi dalam pembelajaran yaitu intelegensi, lingkungan belajar dan metode pembelajaran. Metode pembelajaran daring memerlukan adaptasi dengan pola kebiasaan dan penggunaan tehnologi. Pembelajaran mandiri, tidak langsung dan penugasan yang banyak, memberikan efek psikologi dengan berbagai macam keluhan fisik dan mental. Evaluasi pembelajaran daring melalui hasil pemahaman (kognitif) dan afektif dengan mengacu pada indeks prestasi kumulatif yang di dapatkan mahasiswa selama pembelajaran daring.Tujuan penelitian untuk mengetahui hubungan aspek psikologi pembelajaran daring masa pandemi Covid-19 dengan capaian Indeks Prestasi Kumulatif mahasiswa vokasi.

Desain penelitian menggunakan deskriptif cros sectional. Populasi dalam penelitian adalah seluruh mahasiswa Prodi D3 Keperawatan STIKES Karya Husada Semester 2. Teknik pengambilan data Total Sampling. Jumlah sampel 71 responden. Variabel independent yaitu aspek psikologi mahasiswa vokasi menghadapi pembelajaran daring dan variable dependent adalah capaian Indeks Prestasi Kumulatif mahasiswa. Pengukuran aspek psikologi menggunakan instrument skala resiliensi aspek psikologi dan Indeks Prestasi Kumulatif menggunakan penilaian acuan normatif. Jenis uji yang digunakan adalah Uji Chi Square dengan nilai $p<0,005$.

Sebagian besar responden $(59,15 \%)$ mempunyai aspek psikologi positif saat pembelajaran daring dan mempunyai capaian IPK sangat memuaskan $(56,34 \%)$. Hasil uji korelasi nilai menunjukkan significancy 0,000 maka ada hubungan antara aspek psikologis pembelajaran daring dengan capaian Indeks Prestasi Kumulatif mahasiswa vokasi.

Kondisi pembelajaran yang memberikan implikasi pada respon individu memperlihatkan pendidikan sebagai institusi mampu menyiapkan mahasiswa menghadapi pembelajaran daring dengan baik. Kondisi yang dapat menunjang proses pembelajaran, fasilitator, perangkat akademik dan metode pembelajaran yang cukup bervariatif, meningkatkan kemampuan mahasiswa dalam mengikuti setiap proses pembelajaran. Target kompetensi yang diusahakan tetap optimal, meskipun tidak ideal akan sangat membantu mahasiswa mencapai hasil pembelajaran yang baik.

Kesimpulan penelitian capaian hasil belajar dapat dipengaruhi oleh minat, motivasi, kemampuan kognitifkemampuan membagi waktu, hubungan dengan keluarga, penjelasan dosen dan suasana tempat tinggal, kondisi sosial dan kemampuan individu dalam beradaptasi dengan kondisi pembelajaran.
\end{abstract}

Kata kunci: Aspek Psikologi, Indeks Prestasi Kumultaif, Pembelajaran Daring

\section{Abstract}

Changes that occur in the learning process due to the pandemic have an impact on the psychological aspects of students. Factors that influence the psychological aspects of learning are intelligence, learning environment and learning methods. Online learning methods require adaptation to habitual patterns and use of technology. Independent learning, indirect and multiple assignments, give psychological effects with a variety of physical and mental complaints. Evaluation of online learning through comprehension (cognitive) and affective results with 
reference to the cumulative grade point average obtained by students during online learning. The research objective was to determine the relationship between the psychological aspects of online learning (during the Covid-19 pandemic with the achievement of the Grade Point Average of vocational students.

The research design used a descriptive cross sectional. The population in the study were all Diploma Nursing students of STIKES Karya Husada Semester 2. Data collection techniques were Total Sampling. The samples is 71 respondents. The independent variable is psychological aspect of vocational students facing online learning and the dependent variable is the achievement of the student's Grade Point Average. The measurement of psychological aspects uses a scale instrument of psychological aspects of resilience and the Grade Point Average uses a normative reference assessment. The type of test used is the Chi Square test with $p$ value $<0.005$.

Most of the respondents (59.15\%) had a positive psychological aspect when learning online and had a very satisfying GPA (56.34\%). The result of the value correlation test shows a significance of 0.000 , so there is a relationship between the psychological aspects of online learning and the achievement of the Grade Point Average of vocational students.

Learning conditions that have implications for individual responses show that education as an institution is able to prepare students for online learning well. Conditions that can support the learning process, facilitators, academic tools and learning methods are quite varied, increasing the ability of students to follow each learning process. The competency target that is sought is still optimal, although not ideal, it will greatly help students achieve good learning outcomes.

The conclusion of this research is that learning outcomes can be influenced by interest, motivation, cognitive abilities, ability to share time, relationships with family, lecturers' explanations and living conditions, social conditions and individual ability to adapt to learning conditions.

Keywords: Psychological aspects, Grade Point Average, Online learning

\section{Pendahuluan}

Coronavirus merupakan virus yang menyebabkan penyakit mulai dari gejala ringan hingga berat. Jenis Coronavirus yang dapat menimbulkan gejala berat seperti Middle East Respiratory Syndrome (MERS) dan Severe Acute Respiratory Syndrome (SARS) (Kementerian Kesehatan, 2020).World Health Organization memberi nama virus baru dengan servere Acute Respiratory Syndrome Coronavirus-2 (SARSCoV-2) dan nama penyakitnya sebagai Coronavirus Disease 2019 (Covid-19) (WHO, 2020). Gejala Covid-19 antara lain gejala gangguan pernapasan akut seperti demam, sesak napas, dan batuk kering. Gejala-gejala tersebut muncul ketika tubuh bereaksi melawan virus Corona (Pane, 2020).

Penyebaran virus yang semakin luas atau yang disebut pandemi menyebabkan perubahan pada semua aspek kehidupan termasuk kegiatan pembelajaran dalam sistem pendidikan. Perubahan pembelajaran memberikan pengaruh secara psikologis bagi mahasiswa. Pola pembelajaran dari tatap muka langsung menjadi tidak ada tatap muka secara langsung, dan hanya menggunakan teknologi dan aplikasi memberikan perubahan dalam adaptasi baik secara fisik, psikologis dan sosial.

Aspek psikologi merupakan suatu aspek penunjang yang menjadikan seseorang berhasil dalam menyelesaikan tugasnya. Keberhasilan yang menjadikan seseorang dapat menyelesaikan tugasnya dengan baik. Aspek psikologi mahasiswa dalam pembelajaran harus diperhatikan sebagai komponen penting yang dapat menunjang keberhasilan mahasiswa, salah satunya penilaian evaluasi akhir capaian pembelajaran (Yoni S, 2017). Aspek psikologi manusia meliputi aspek emosional, aspek kognitif dan aspek interpersonal (Calvin dan Lindzey, 2005). Aspek psikologi dalam pembelajaran yaitu intelegensi, minat, sikap, motivasi dan kreativitas (Widia Hapnita, Rijal Abdullah, Yuwalitas Gusmareta dan Fahmi Rizal, 2018).

Corona Virus Disease pada tahun 2019 atau Covid-19 telah menjadi pandemi global semenjak diumumkan oleh WHO pada tanggal 11 Maret 2020. Diduga Covid-19 pertama kali muncul di Wuhan, Provinsi Hubei, Tiongkok. Virus ini diduga muncul karena adanya sebuah pasar makanan di Wuhan yang menjual bebagai jenis hewan 
hidup maupun sudah mati (Nuraini, 2020). Virus tersebar di seluruh dunia, termasuk Indonesia sejak awal bulan Maret 2020.I

Jumlah kasus konfirmasi di Indonesia sampai tanggal 15 Agustus 2020, kasus positif Covid-19 mencapai 137.468 dan 91.321 dinyatakan sembuh, meninggal 6071 kasus. Presentase kesembuhan 66,4 \% dari total kasus konfirmasi (Kementrian Kesehatan, 2020). Data menyebutkan di Jawa Timur tanggal 15 Agustus 2020 terdapat 11.329 pasien mengalami suspect Covid-19, 27.415 terkonfirmasi positif Covid-19 dengan rincian data kasus sembuh 20.471, pasien dirawat 4.956 dan 1.988 meninggal akibat terkonfirmasi positif Covid-19. Kasus Covid19 di Surabaya sampai tanggal 15 Agustus 2020 terdapat 10.515 yang terkonfirmasi positif Covid-19 dengan 7.305 sembuh dan 849 jiwa meninggal (Dinas Kesehatan Pemprov Jawa Timur, 2020). Gugus tugas percepatan penanganan Covid-19 Kabupaten Kediri tanggal 15 Agustus 2020 melaporkan terdapat kasus terkonfirmasi positif Covid-19 yaitu 551 dengan rincian data 388 pasien sembuh, 133 dalam masa perawatan dan 30 meninggal. Kasus pemantauan (suspect) sebanyak 101 (Dinas Kesehatan Kabupaten Kediri, 2020).

Perubahan yang terjadi dalam metode pembelajaran pendidikan dengan adanya pandemi, salah satunya adanya pada aspek psikologi dari mahasiswa.Hasil penelitian dari Fang, Hou, Han, Xu, Dong \& Zheng, (2020) pada 7.143 mahasiswa menunjukkan bahwa $0,9 \%$ mahasiswa mengalami ansietas berat, 2,7\% mengalami ansietas sedang dan 21,3\% mengalami ansietas ringan (Livana, Mohammad Fatkhul Mubin dan Yazid Basthomi, 2020). Hasil penelitian di Indonesia menunjukkan adanya perubahan aspek psikologis pada mahasiswa dengan adanya pembelajaran daring antara lain 19,6\% dari total responden mengaku cemas dan khawatir, $12,5 \%$ merasa bosan, $9 \%$ merasa kehilangan kemampuan penguasaan materi dan 8,3\% merasa butuh liburan (Annisa Lestari Kadiyono, 2020). Penelitian di kampus Telkom University dan UIN Bandung menunjukkan sekitar $60,5 \%$ mahasiswa beradaptasi dengan penggunaan teknologi pembelajaran perkuliahan daring tetapi sekitar 59,5\% keberatan akan tugas diberikan dosen yang berakibat tingkat stress mahasiswa sekitar 60\% (Agus Kusnayat, Moh. Hifzul
Muiz, Nani Sumarni, Agus Salim Mansyur, dan Qiqi Yulanti Zaqilah, 2020). Hasil penelitian terkait capaian Indeks Prestasi Kumulatif dalam penelitian Erika U, 2020 menyebutkan pembelajaran daring memberikan gambaran Indeks Pretasi Kumulatif, yakni sebagian besar dari responden (52\%) mempunyai Indeks Prestasi Akademik memuaskan.

Pandemi corona virus disease 2019 atau COVID-19 yang telah melanda 215 negara di dunia, memberikan tantangan tersendiri bagi lembaga pendidikan, khususnya pada Perguruan Tinggi. Pemerintah Indonesia langsung menindak lanjuti kasus tersebut dengan melakukan Social Distancing selama 14 hari untuk meminimalisir penyebaran virus tersebut. Menurut Center for Disease (CDC) Social Distancing yaitu menjauhi perkumpulan, menghindari pertemuan massal, dan menjaga jarak antar manusia. Pembatasan sosial atau menjaga jarak yang dilakukan untuk mencegah penularan COVID-19 agar tidak menyebar luas (Kosasih, 2020). Pemerintah melarang untuk berkerumun, pembatasan sosial atau social distancing dan menjaga jarak fisik atau physical distancing, memakai masker dan selalu cuci tangan. Kementerian Pendidikan dan Kebudayaan Pemerintah melarang perguruan tinggi untuk melaksanakan perkuliahan tatap muka atau konvensional dan memerintahkan untuk menyelenggarakan perkuliahan atau pembelajaran secara daring (Surat Edaran Kemendikbud Dikti No. 1 tahun 2020). Perguruan tinggi dituntun untuk dapat menyelenggarakan pembelajaran secara daring atau online (Firman, F \& Rahayu, S, 2020).

Bulan Maret 2020 lebih dari 800 juta siswa di dunia melakukan pembelajaran di rumah sebagai akibat dari pandemi COVID19 yang tengah mewabah ini (Arika, 2020). Menteri Pendidikan dan Kebudayaan (Mendikbud) Indonesia juga membuat kebijakan terkait belajar di rumah bahkan membatalkan ujian nasional 2020 (Asmara, 2020). Kebijakan belajar di rumah ini dilakukan untuk mengurangi interaksi fisik sebagai upaya pencegahan penularan virus corona jenis baru atau COVID-19. Mendikbud sangat berharap dengan diterapkannya pembelajaran daring atau jarak jauh ini siswa juga mendapatkan pengalaman baru dalam proses belajar (Fajar, 2020). 
Proses pembelajaran dapat berjalan dengan baik dengan adanya teknologi informasi yang sudah berkembang pesat saat ini diantaranya google class, e-learning, whatsapp, zoom serta media infromasi lainnya serta jaringan internet atau sering disebut juga dengan sistem pembelajaran dalam jaringan (daring) (Pakpahan \& Fitriani, 2020). Daring atau dalam jaringan merupakan salah satu bentuk pemanfaatan internet yang dapat meningkatkan peran mahasiswa dalam proses pembelajaran (Saifuddin, 2016).

Perkembangan teknologi dapat memberikan manfaat dalam kegiatan pembelajaran jarak jauh selama pembatasan sosial ditengah pandemi Covid-19 (Pakpahan \& Fitriani, 2020). Pembelajaran jarak jauh dengan penggunaan internet terkendala masih ada yang belum bisa menggunakan internet secara tepat dan dengan penerapan pembelajaran jarak jauh (distance learning) meningkatkan kecemasan pada mahasiswa (Oktawirawan, 2020). Kecemasan mempengaruhi kondisi kesehatan salah satunya adalah aspek psikologi. Psikologi adalah semua tingkah laku dan perbuatan manusia (individu), yang berkaitan dengan lingkungan dan kondisi (Budi Hartono, 2020). Proses pembelajaran yang komprehensif melibatkan aspek psikologis dan harus mendapat perhatian untuk diketahui. Aspekaspek psikologi dalam pembelajaran meliputi intelegensi, minat, sikap, motivasi dan aktivitas serta kreativitas yang timbul atau berkembang dalam proses pembelajaran (S.Erita, 2016).

Faktor yang mempengaruhi aspek psikologi dalam suatu pembelajaran antara lain intelegensi, lingkungan belajar dan metode pembelajaran (Umar, 2002). Intelegensi adalah kemampuan memecahkan masalah serta beradaptasi dan belajar dari pengalaman yang dijalaninya. Lingkungan pembelajaran mempengaruhi dalam memecahkan suatu masalah yang dialami dalam lingkungan dengan pola pikir dan pemecahan masalah dapat dilatih dengan baik. Metode pembelajaran mempengaruhi aspek psikologi karena setiap metode pembelajaran yang digunakan memerlukan adaptasi sehingga apabila mahasiswa tidak mampu berapdasi maka akan mempengaruhi aspek psikologisnya.

Berbagai dampak dan kendala juga muncul dalam penerapan pembelajaran daring. Pembelajaran melalui internet menjadi hal yang sulit dilakukan dibeberapa daerah tertentu dengan jaringan yang tidak memadai (Hastini et al. 2020). Penggunaan kuota internet juga memunculkan pengeluaran biaya baru yang bisa menjadi masalah bagi beberapa mahasiswa yang mengalami kesulitan finansial. Adanya perbedaan kecepatan akses teknologi yang dimiliki setiap mahasiswa membuat beberapa mahasiswa kesulitan dalam mengikuti pembelajaran dengan lancar (Morgan, 2020). Banyaknya tugas yang diberikan membuat mahasiswa merasa stres dalam menjalani pembelajaran daring (Chaterine, 2020).

Dampak pandemi COVID-19 pada berbagai aspek kehidupan salah satunya pada bidang pendidikan yang harus menerapkan pembelajaran daring, sehingga pada awal pembelajaran terlihat kurang efektif. Aspek psikologis pada minat terhadap pembelajaran cenderung menurun dikarenakan faktor fasilitas jaringan yang menyebabkan tidak stabilnya pembelajaran saat berlangsung (Hermiza Mardesci \& Alfina Mardesci, 2020). Aspek psikologis dampak pembelajaran daring terhadap sikap antara lain adanya penolakan, penilaian, suka atau tidak suka terhadap pembelajaran daring. Motivasi terhadap pembelajaran selama pandemic mengalami penurunan. Kreatifitas mahasiswa terhambat untuk melakukan explore langsung ke lapangan (Adhetya C, Iin D L \& Sari D L, 2020).

Upaya dan solusi dari pemegang kebijakan yakni pemerintah terkait pendidikan dan pembelajaran, dalam rangka mengurangi dan menurunkan dampak pembelajaran daring dihasilkan Keputusan bersama Kemdikbud, Menteri Agama, Menteri Kesehatan dan Menteri Dalam Negeri No. 03/KB/2020, No. 612 Tahun 2020, No. HK.01.08/Menkes/502/2020 serta No. 199/4536/SJ pada tanggal 07 Agustus 2020 yang semula pembelajaran tatap muka hanya boleh dilakukan pada zona hijau saat ini boleh dilakukan juga pada zona kuning. Pembelajaran tatap muka diperluas sampai dengan zona kuning, dikarenakan zona kuning memiliki resiko penularan Covid-19 rendah berdasarkan hasil pemetaan satuan tugas nasional penanganan Covid-19. Keputusan tersebut diambil menimbang bahwa berdasarkan hasil evaluasi Pemerintah terdapat kebutuhan pembelajaran tatap muka 
dari peserta didik yang mengalami kendala dalam melaksanakan pembelajaran jarak jauh. Siswa juga kesulitan berkonsentrasi belajar dan merasa stress dan jenuh akibat isolasi berkelanjutan (Kemdikbud, 2020). Kondisi pembelajaran yang kurang efektif mempengaruhi capaian prestasi yang meliputi pemahaman, skill kemampuan individu terutama pada pendidikan vokasi dan attitude.

Kesehatan psikososial dalam situasi pandemi diperlukan peran dari semua pihak. Orang tua perlu mengelola dengan baik stress dan emosinya, bersikap tenang dan dapat lebih mendekatkan hubungan dengan anak merupakan salah satu solusi terbaik untuk menjaga psikologisnya. Motivasi dan dukungan dari pendidik dan sesama teman sepergaulan agar tidak merasa cemas dan stress. Cara dalam mengatasi emosi dan mengelola stress yang bisa di lakukan oleh orang tua maupun pendidik diantaranya adalah dengan mengajak berbicara tenang dan penuh kasih sayang, memberikan kesempatan mengekspresikan perasaan dan mengungkapkan isi pikiran, memberikan pujian dan motivasi terkait aktivitas yang dilakukan selama pandemi, membantu melakukan kegiatan yang disukai (hobi) atau yang dapat membuat ketenangan dan mengenali tanda-tanda masalah kejiwaan dan psikososial seperti (gelisah, sedih, bosan, mudah tersinggung, agresif, menyendiri) (Diah Setia Utami, Budi Anna Keliat, Thika Marliana dkk, 2020).

Dari uraian latar belakang diatas adanya pandemi COVID-19 ini memberikan dampak yang sangat besar diberbagai sektor salah satunya dalam bidang pendidikan. Dalam bidang pendidikan, kegiatan belajar harus dilakukan dengan menggunakan pembelajaran daring atau dalam jaringan untuk mengurangi faktor penyebaran virus. Pembelajaran daring mempunyai implikasi pada aspek psikologis mahasiswa yang akan berdampak pada capaian prestasi mahasiswa. Oleh sebab itu, peneliti tertarik untuk meneliti aspek psikologi mahasiswa vokasi menghadapi pembelajaran daring masa pandemi Covid-19 dengan capaian Indeks Prestasi Kumulatif mahasiswa di Prodi D3 Keperawatan STIKES Karya Husada Kediri.

\section{Metode}

Desain penelitian yang digunakan dalam penelitian menggunakan deskriptif Cross
Sectional. Populasi dalam penelitian ini adalah seluruh mahasiswa Semester 2 Prodi D3 Keperawatan STIKES Karya Husada Kediri. Dalam penelitian ini teknik pengambilan data yang digunakan yaitu Total Sampling. Peneliti mengambil sampel di Prodi D3 Keperawatan sebanyak 71 Responden (semua mahasiswa Semester 2).

Variabel independent dalam penelitian yaitu aspek psikologi mahasiswa vokasi menghadapi pembelajaran daring dan variable dependent adalah capaian Indeks Prestasi Kumulatif mahasiswa. Pengukuran aspek psikologi menggunakan instrument skala resiliensi aspek psikologi dan Indeks Prestasi Kumulatif menggunakan Nilai Acuan Normatif. Jenis uji yang digunakan adalah Uji Chi Square dengan nilai significancy $p$ $<0,005$.

\section{Hasil}

Data Umum Tabel 1.1 Karakteristik mahasiswa Semester 2 di Prodi D3 Keperawatan, Agustus 2020 ( $\mathrm{n}=71$ )

\begin{tabular}{|c|c|c|}
\hline Variabel & Frekuensi & $\%$ \\
\hline $\begin{array}{l}\text { Jenis Kelamin: } \\
\text { Laki Laki } \\
\text { Perempuan }\end{array}$ & $\begin{array}{l}11 \\
60\end{array}$ & $\begin{array}{l}15,5 \% \\
84,5 \%\end{array}$ \\
\hline $\begin{array}{l}\text { Fasilitas } \\
\text { Smartphone: } \\
\text { Ya } \\
\text { Tidak }\end{array}$ & $\begin{array}{l}71 \\
0\end{array}$ & $\begin{array}{l}100 \% \\
0 \%\end{array}$ \\
\hline $\begin{array}{l}\text { Kondisi Jaringan di } \\
\text { daerahnya: } \\
\text { Lancar } \\
\text { Kurang Lancar } \\
\text { Tidak Lancar }\end{array}$ & $\begin{array}{l}33 \\
38 \\
0\end{array}$ & $\begin{array}{l}46,5 \% \\
53,5 \% \\
0 \%\end{array}$ \\
\hline $\begin{array}{l}\text { Aplikasi Daring } \\
\text { yang disukai } \\
\text { Langsung } \\
\text { (Zoom,dll) } \\
\text { Tidak Langsung } \\
\text { (Google } \\
\text { Classroom,dll) } \\
\end{array}$ & $\begin{array}{l}38 \\
33\end{array}$ & $\begin{array}{l}53,5 \% \\
46.5 \%\end{array}$ \\
\hline $\begin{array}{l}\text { Minat Belajar Saat } \\
\text { Pandemi: } \\
\text { Meningkat } \\
\text { Tetap } \\
\text { Menurun }\end{array}$ & $\begin{array}{l}7 \\
32 \\
32\end{array}$ & $\begin{array}{l}9,9 \% \\
45,1 \% \\
45,1 \%\end{array}$ \\
\hline $\begin{array}{l}\text { Sikap Belajar: } \\
\text { Positif } \\
\text { Negatif }\end{array}$ & $\begin{array}{l}61 \\
10\end{array}$ & $\begin{array}{l}85,9 \% \\
14,1 \%\end{array}$ \\
\hline $\begin{array}{l}\text { Motivasi Belajar } \\
\text { saat Pandemi: } \\
\text { Tinggi } \\
\text { Sedang } \\
\text { Rendah }\end{array}$ & $\begin{array}{l}11 \\
58 \\
2 \\
\end{array}$ & $\begin{array}{l}15,5 \% \\
81,7 \% \\
2,8 \% \\
\end{array}$ \\
\hline $\begin{array}{l}\text { Kreatifitas Belajar: } \\
\text { Tinggi } \\
\text { Sedang } \\
\text { Rendah }\end{array}$ & $\begin{array}{l}21 \\
49 \\
1 \\
\end{array}$ & $\begin{array}{l}29,6 \% \\
69 \% \\
1,4 \% \\
\end{array}$ \\
\hline
\end{tabular}




\begin{tabular}{lll}
\hline Dukungan Orang & & \\
Tua & & \\
Selalu & 53 & $74,6 \%$ \\
Kadang-Kadang & 18 & $25,4 \%$ \\
Tidak pernah & & $0 \%$ \\
\hline $\begin{array}{l}\text { Kelompok Belajar } \\
\text { (Diskusi Online) }\end{array}$ & & \\
Ada & & \\
Tidak Ada & 40 & $56,3 \%$ \\
& 31 & $43,7 \%$ \\
\hline
\end{tabular}

Pada tabel 1.1 menunjukkan bahwa hampr seluruh responden berjenis kelamin perempuan (60 responden/ 84,5\%), seluruh responden memiliki Smartphone (100 responden/ 100\%), sebagian besar responden kurang lancar akses internet di daerahnya (38 responden/ 53,5\%),sebagian besar menyukai aplikasi pembelajaran daring secara langsung misal, Zoom (38 responden/ 53,5\%), hampir setengah responden mempunyai minat belajar yang tetap dan menurun (32 responden/ $45,1 \%$ ), hampir seluruh responden memiliki sikap belajar positif (61 responden/ 85,9\%), hampir seluruh responden memiliki motivasi belajar sedang (58 responden/ 81,7\%), sebagian besar responden memiliki kreatifitas belajar yang sedang (49 responden/ 69\%), sebagian besar responden selalu mendapat dukungan dari orang tua saat pembelajaran daring (53 respoden/ 74,6\%), dan sebagian besar responden memiliki kelompok belajar untuk berdiskusi saat pembelajaran daring (40 responden/ 56,3\%).

Data Khusus

1. Aspek Psikologi Pembelajaran Daring

Tabel 1.2 Aspek psikologi mahasiswa Semester 2 menghadapi pembelajaran daring masa pandemi Covid-19 di Prodi D3 Keperawatan, Agustus $2020(n=71)$

\begin{tabular}{lcl}
\hline Variabel & Frekuensi & $\%$ \\
\hline Aspek Psikologi & & \\
Positif & & \\
Negatif & 42 & $59,15 \%$ \\
& 29 & $40,85 \%$ \\
\hline Total & 71 & $100 \%$ \\
\hline
\end{tabular}

Berdasarkan tabel diatas, sebagian besar responden (42 responden/ 59,15\%) mempunyai aspek psikologi positif saat pembelajaran daring.

2. Capaian Indeks Prestasi Kumulatif Mahasiswa Vokasi

Tabel 1.3 Capaian Indeks Prestasi Akademik mahasiswa Semester 2 di Prodi D3 Keperawatan, Agustus $2020(n=71)$

\begin{tabular}{lcc}
\hline Variabel & Frekuensi & \% \\
\hline Capaian Indeks & & \\
Prestasi Kumulatif: & & \\
& & \\
Memuaskan & 7 & $9,86 \%$ \\
Sangat Memuaskan & 40 & $56,34 \%$ \\
Pujian & & \\
& 24 & $33,8 \%$ \\
\hline Total & 71 & $100 \%$ \\
\hline
\end{tabular}

Berdasarkan tabel diatas, sebagian besar responden (40 responden/ 56,34\%) mempunyai capaian IPK sangat memuaskan.

3. Tabulasi Silang

Tabel 1.4 Tabulasi silang aspek psikologi dengan capaian Indeks Prestasi Kumulatif mahasiswa

Semester 2 di Prodi D3 Keperawatan, Agustus $2020(n=71)$

\begin{tabular}{|c|c|c|c|}
\hline Variabel & Aspek P & $\log i$ & \\
\hline Capaian IPK & Positif & Negatif & Total \\
\hline Memuaskan & $\begin{array}{l}2 \\
4,76 \%\end{array}$ & $\begin{array}{l}5 \\
17,24 \%\end{array}$ & $\begin{array}{l}7 \\
9,86 \%\end{array}$ \\
\hline $\begin{array}{l}\text { Sangat } \\
\text { Memuaskan }\end{array}$ & $\begin{array}{l}27 \\
64,29 \%\end{array}$ & $\begin{array}{l}13 \\
44,83 \%\end{array}$ & $\begin{array}{l}40 \\
56,34 \%\end{array}$ \\
\hline Pujian & $\begin{array}{l}13 \\
30,95 \%\end{array}$ & $\begin{array}{l}11 \\
37,93 \%\end{array}$ & $\begin{array}{l}24 \\
33,8 \%\end{array}$ \\
\hline Total & $\begin{array}{l}42 \\
59,15 \%\end{array}$ & $\begin{array}{l}29 \\
40,85 \%\end{array}$ & $\begin{array}{l}71 \\
100 \%\end{array}$ \\
\hline
\end{tabular}

Berdasarkan tabel diatas, sebagian besar responden (27 responden/ 64,29\%) mempunyai aspek psikologi positif dengan capaian Indeks Prestasi Akademik Semester 2 dengan hasil sangat memuaskan.

Analisis hubungan aspek psikologi dengan capaian Indeks Prestasi Akademik mahasiswa Semester 2 di Prodi D3 Keperawatan, Agustus $2020(n=71)$

Tabel 1.5 Hasil Uji Chi Square Test Statistics

\begin{tabular}{lll}
\hline & $\begin{array}{l}\text { Aspek } \\
\text { Psikologi }\end{array}$ & CapaianIPK \\
\hline Chi-Square & $2.380^{\mathrm{a}}$ & $23.014^{\mathrm{b}}$ \\
\hline Df & 1 & 2 \\
\hline Asymp. Sig. & .123 & .000 \\
\hline
\end{tabular}

\section{Pembahasan}

a. Aspek Psikologi Pembelajaran Daring

Berdasarkan hasil penelitian didapatkan bahwa sebagian besar responden (42 responden/ 59,15\%) mempunyai aspek psikologi positif saat pembelajaran daring. 
Aspek psikologi merupakan aspek penunjang untuk mencapai keberhasilan dalam menyelesaikan tugas. Keberhasilan yang menjadikan seseorang dapat menyelesaikan tugasnya dengan baik (Handayani, 2011). Aspek psikologis mahasiswa dalam pembelajaran harus diperhatikan sebagai komponen penting yang menunjang keberhasilan siswa. Perubahan dalam proses pembelajaran akan memberikan pengaruh pada kemampuan kognitif dan perubahan afektif.

Aspek psikologi meliputi aspek emosional, aspek kognitif dan aspek interpersonal (Calvin dan Lindzey, 2005). Proses kehidupan manusia dikaitkan dengan yang dirasakan (emosional), dipikirkan (kognitif) dan yang diperbuat (hubungan interpersonal). Emosi berkaitan perasaan (feeling), perilaku

(behaviour), perubahan fisiologis (physiological change), dan kognisi. Fungsi utama emosi adalah untuk memberi informasi kepada individu mengenai interaksinya dengan dunia luar (Strongman, 2006). Kognitif merupakan proses berpikir dimana informasi dari pancaindera ditransformasi, direduksi, dielaborasi, diperbaiki, dan digunakan (Neisser dalam Morgan, et al. Melly Latifah, 2008).

Faktor yang mempengaruhi aspek psikologi dalam pembelajaran antara lain intelegensi, lingkungan belajar dan metode pembelajaran (Umar, 2002). Intelegensi merupakan suatu kecerdasan. Lingkungan berpengaruh terhadap perkembangan individu. Metode pembelajaran merupakan cara yang digunakan pemberi pembelajaran dalam menjalankan fungsinya dan merupakan alat untuk mencapai tujuan pembelajaran.

Penggunaan metode pembelajaran yang bervariasi akan memberikan suasana belajar yang menarik dan tidak membosankan. Akan tetapi, bisa saja penggunaan metode yang bervariasi atau baru menjadikan pembelajaran tidak efektif jika penggunaanya kurang tepat, salah satunya metode pembelajaran daring yang kurang tepat di berikan pada pensisikan vokasi akan memberikan implikasi penurunan pemahaman dan kompetensi mahasiswa.

Hampir seluruh responden memiliki sikap belajar positif (61 responden/ 85,9\%). Komponen dari aspek psikologi salah satunya adalah sikap belajar mahasiswa. Sikap mencerminkan kecenderungan dan perasaan, kecurigaan dan prasangka, pemahaman yang mendetail, ide-ide, rasa takut, ancaman dan keyakinan tentang suatu hal atau situasi tertentu. sikap dapat berbentuk pengaruh atau penolakan, penilaian, suka atau tidak suka, atau kepositifan atau kenegatifan terhadap sesuatu.

Dampak pandemi COVID-19 salah satunya pada bidang pendidikan adalah menerapkan pembelajaran daring. Kondisi pembelajaran daring yang sudah dikondisikan dengan baik, akan memberikan respon positif dan mahasiswa berusaha mengikuti serta beradaptasi. Penilaian pembelajaran daring oleh mahasiswa menjadi suatu keharusan dalam situasi tertentu. Kondisi yang pada awalnya kurang menyenangkan menjadi lebih bervariatif dengan bebragai macam saran dan prasarana serta aplikasi dalam tehnologi memberikan pemahaman yang positif bagi kemajuan perkembangan pembelajaran jarak jauh/ daring.

Hampir setengah responden mempunyai minat belajar yang tetap dan menurun (32 responden $(45,1 \%)$. Minat merupakan kecendrungan yang ada dalam diri karena merasa tertarik pada bagian tertentu dan merasa senang pada hal tententu. Seseorang yang memiliki minat terhadap sesuatu akan merasa tertarik dan senang melakukan berbagai kegiatan dan usaha yang berkaitan dengan hal tersebut.

Minat merupakan bagian dari aspek psikologi mahasiswa dalam mengikuti pembelajaran. Minat erat kaitannya dengan aktivitas yang akan di jalani yang memiliki intensitas dan perlunya kesiapan untuk melakukan. Sebuah pembelajaran yang membutuhkan adaptasi baru dengan memahami konsep baru, akan menimbulkan aktifitas yang terus menerus di lakukan.

Mahasiswa vokasi yang prosentase pembelajarannya lebih banyak di lapangan, akan memberikan implikasi yang sangat besar terhadap pembelajaran yang dilakukan melalui daring. Mahasiswa akan merasa semangat dan keinginan melakukan aktifitas pembelajaran menjadi menurun. Mahasiswa kebingungan dengan konsep yang di terima tanpa ada gambaran bagaimana melakukannya.

Hampir seluruh responden memiliki motivasi belajar sedang (58 responden/ 81,7\%). Motivasi merupakan kecenderungan untuk bertindak dengan satu cara tertentu. Pada keadaan tertentu dalam pribadi 
seseorang mampu mendorong keinginan individu untuk melakukan kegiatan untuk mencapai tujuan yang diinginkannya. Motivasi sangat penting dalam proses pembelajaran, karena mengarahkan tindakan, serta memilih tujuan belajar yang dirasa paling berguna bagi kehidupan.

Mahasiswa yang memiliki motivasi tinggi akan memliki ciri ciri kuat memikul tanggung jawab dalam meyelesaikan masalah, memiliki prestasi dan keinginan kuat untuk mendapatkan sesuatu yang konkrit atas tugas yang dikerjakan. Adanya pemikiran sebelum mengerjakan tugas-tugas dan berupaya untuk menyempurnakan tugas tersebut.

Mahasiswa vokasi yang di tuntut memiliki kompetensi skill konkrit (kemampuan dalam mempraktekkan hal hal yang sesuai dengan teori atau konsep), dalam kondisi pembelajaran daring akan sedikit mengalami kesulitan dalam pelaksanaanya. Mereka yang seharusnya pembelajaran langsung di laboratorium, menggunakan alat atau saran prasarana langsung, tiba tiba di ubah pembelajarannya dengan daring yang mungkin hanya mampu di bayangkan tanpa aplikasi langsung.

Kondisi pembelajaran praktek lapangan yang seharunya dilakukan untuk target kompetensi mereka juga mengalami kesulitan dengan pembelajarn daring. Kondisi ini menimbulkan kekhawatiran pada mereka terkait apa yang didapatkan selama pembelajaran, apakah mampu mereka lakukan saat mereka harus terjun sebagai tenaga professional kelak.

Fungsi motivasi menjadikan mahasiswa mengetahui arah tujuan dari pembelajaran yang akan mereka capai. Kondisi pembelajaran pada pendidikan vokasi perlu modifikasi lebih banyak dan bervariasi supaya tujuan pembelajaran dapat dicapai dan mahasiswa tidak mengalami kekhawatiran pada apa yang harusnya mereka fahami dan kuasai dalam prose pembelajaran.

\section{b. Capaian Indeks Prestasi Kumulatif}

Berdasarkan hasil penelitian didapatkan bahwa sebagian besar responden (40 responden $(56,34 \%)$ mempunyai capaian IPK sangat memuaskan.

Faktor yang mempengaruhi capaian hasil belajar diantaranya adalah manajemen diri, factor lingkungan sekitar, faktor kondisi eksternal,faktor kondisi fisik dan faktor olahraga. Faktor yang mempengaruhi hasil belajaryaitu faktor internal, yang mencakup aspek fisik, misalnya kesehatan organ tubuh, aspek psikis, misalnya intelektual, emosional, motivasi, dan aspek sosial, misalnya kemampuan bersosialisasi dengan lingkungan. Faktor eksternal, misalnya variasi dan derajat kesulitan materi yang dipelajari, tempat belajar, iklim, suasana lingkungan, budaya belajar masyarakat (Anni, 2004).

Faktor- faktor yang mempengaruhi hasil belajar meliputi faktor dalam, yaitu fisiologis seperti kondisi panca indra serta psikologis yang menyangkut minat, tingkat kecerdasan, bakat, motivasi, dan kemampuan kognitif. Faktor luar yaitu kurikulum, guru, sarana dan fasilitas serta manajemen yang berlaku di sekolah (tempat belajar) yang bersangkutan (Purwanto, 2004).

Indeks Prestasi Kumulatif merupakan target penilaian numerik atau angka yang menunjukkan ketercapaian sebuah pembelajaran. Indeks Prestasi Akademik diperoleh melalui proses pembelajaran yang diterjemahkan dari Kurikulum yang disepakati oleh Assosiasi Pendidikan terkait kompetensi apa yang harus dicapai mahasiswa.

Pencapaian Indeks Pretasi Kumulatif melalui proses pembelajaran teori/ konsep yang merupakan pencapaian knowledge, pembelajaran laboratorium yang merupakan pencapain knowledge dan psikomotor, serta komunikasi, prilaku yang merupakan pencapaian dalam attitude nya.

Hasil belajar ditunjukkan secara riil melalui angka pencapaian IPK yang kemudia dapat disebutkan secara diskriptif rentang capaian tersebut dengan sebuatan pujian, sangat memuskan, dan memuaskan. Hasil belajar pada mahasiswa vokasi terdistribusi secara proposional pada pembelajaran konsep. Teori dengan pembelajaran praktikum. Kondisi pembelajaran daring merupakan faktor external dari faktor yang memprengaruhi hasil belajar, yakni variasi dalam pembelajaran karena kondisi yang memaksa terjadinya pembelajarn tersebut.

\section{c. Korelasi Aspek Psikologi Pembelajaran \\ Daring dengan Capaian Indeks Prestasi Kumulatif Mahasiswa Vokasi}

Berdasarkan hasil penelitian didapatkan bahwa sebagian besar responden (27 responden/ 64,29\%) mempunyai aspek psikologi positif dengan capaian Indeks Prestasi Akademik Semester 2 dengan hasil sangat memuaskan. Hasil uji korelasi 
didapatkan nilai significancy 0,000 yang berarti bahwa $p$ value $<0,05$ (ada hubungan).

Telah di sebutkan bahwa capaian hasil belajar dapat dipengaruhi oleh beberapa faktor salah satunya adalah faktor psikologis yang menyangkut minat, tingkat kecerdasan, bakat, motivasi, dan kemampuan kognitif (Purwanto, 2004). Pembelajaran daring mempunyai implikasi pada aspek psikologis mahasiswa yang akan berdampak pada capaian prestasi mahasiswa.

Hasil penelitian ini sesuai dengan penelitian Erika U, 2020 menyebutkan pembelajaran daring memberikan gambaran Indeks Pretasi Kumulatif, yakni sebagian besar dari responden (52\%) mempunyai Indeks Prestasi Akademik memuaskan. Hasil penelitian ini juga sesuai Penelitian Agus Kusnayat, Moh. Hifzul Muiz, Nani Sumarni, Agus Salim Mansyur, dan Qiqi Yulanti Zaqilah, 2020 yang melaksanakan Penelitian di kampus Telkom University dan UIN Bandung menunjukkan sekitar 60,5\% mahasiswa beradaptasi dengan penggunaan teknologi pembelajaran perkuliahan daring .

Faktor lain yang memberikan pengaruh terhadap capaian hasil belajar selain aspek psikologi, dimungkinkan karena adanya faktor dari luar atau external. Kondisi pembelajaran saat ini yang kecenderungan memberikan implikasi pada masing masing respon individu akan memperlihatkan bagaimana pendidikan sebagai institusi menyiapkan mahasiswa menghadapi pembelajaran daring dengan baik.

Kondisi yang dapat menunjang proses pembelajaran, fasilitator, perangkat akademik dan metode pembelajaran yang cukup bervariatif, meningkatkan kemampuan mahasiswa dalam mengikuti setiap proses pembelajaran.

Target kompetensi yang diusahakan tetap optimal, meskipun tidak ideal akan sangat membantumahasiswa mencapai hasil pembelajaran yang baik.

Capaian hasil belajar dapat dipengaruhi oleh dukungan keluarga, kondisi sosial dan kemampuan individu dalam beradaptasi dengan kondisi pembelajaran. Motivasi yang diberikan dari pihak luar, misal orang tua dan pengajar memberikan nilai nilai positif bagi mahaisswa untuk tetap semnagat belajar meskipun dalam keterbatasan.

Manajemen diri mahasiswa yang meliputi kemampuan membagi waktu, hubungan dengan keluarga, penjelasan dosen dan suasana tempat tinggal juga kemungkinan dapat mempengaruhi hasil belajar mahasiswa.

\section{Kesimpulan}

Sebagian besar responden mempunyai aspek psikologi positif saat pembelajaran daring.dengan capaian Indeks Prestasi Kumulatif sangat memuaskan. Hasil uji korelasi nilai menunjukkan significancy 0,000 maka ada hubungan antara aspek psikologi pembelajaran daring dengan capaian Indeks Prestasi Kumulatif mahasiswa vokasi. Capaian hasil belajar dapat dipengaruhi oleh minat, motivasi, kemampuan kognitif kemampuan membagi waktu, hubungan dengan keluarga, penjelasan dosen dan suasana tempat tinggal, kondisi sosial dan kemampuan individu dalam beradaptasi dengan kondisi pembelajaran.

\section{Saran}

1. Diharapkan pemerintah sebagai pemegang kebijakan melalui Mentri Pendidikan dan kebudayaan untuk mengatur regulasi proses pembelajaran daring

2. Institusi pendidikan memfasilitasi konseling psikologi pada mahasiswa yang mengalami kekhawatiran dan kebingungan serta kebosanan dengan adanya pembelajaran daring.

3. Orang tua sebagai pendidik utama dalam kondisi pembelajaran daring, diharapkan dapat memberikan dukungan secara optimal melalui pemberian fasilitas, saran dan prasarana serta waktu bersama dengan banyak mengapresiasi anak meskipun kondisi pembelajaran jarak jauh masih dilakukan bersama dengan pengajar.

\section{Daftar Pustaka}

Anni, Catharina Tri.2004. Psikologi Belajar. Semarang. Unnes Press.

Agung, I. M., Psikologi, F., Islam, U., Sultan, N., \& Kasim, S. (2020). Memahami Pandemi COVID-19 dalam Perspektif Psikologi Sosial. 1(2), 68-84.

Cahyani, A., Listiana, I. D., Puteri, S., Larasati, D., Islam, U., Sunan, N., Yogyakarta, K., Islam, U., Sunan, N., Yogyakarta, K., Islam, U., Sunan, N., Yogyakarta, K., \& Belajar, M. (2020). Motivasi Belajar Siswa SMA pada Pembelajaran Daring di Masa 
Pandemi Covid-19. 3(01), 123-140. https://doi.org/doi.org/10.37542/iq.v3i01.57

Donsu, J. D. T. (2019). Psikologi Keperawatan. Pustaka Baru.

Erita, S. (2016). Aspek-Aspek Psikologis dalam Pembelajaran.1-11. ejournal.iainkerici.ac.id

Erika Untari D, 2020. Pengaruh Kecemasan Saat Pembelajaran Daring Masa Pandemi Covid19 Terhadap Prestasi Belajar Mahasiswa Stikes William Surabaya. Jurnal Keperawatan, $\quad 9(1)$, 18 23.https://doi.org/10.47560/kep.v9i1.210

Hidayat, A. A. (2011). Metode Penelitian Kebidanan dan Teknik Analisis Data. Salemba Medika.

Islam, U., \& Walisongo, N. (2019). Formulasi Model Perkuliahan Daring Sebagai Upaya Menekan Disparitas Kualitas Perguruan Tinggi. 1(2), 151-160. http://journal.walisongo.ac.id/index.php/jit/i ndex\%0AWJIT

Kuntarto, E. (2017). Journal Indonesian Language Education and Literature. 3(1), 99-110. https://doi.org/DOI:http://dx.doi.org/10.242 35/ileal.v3i1.1820

Kusnayat, A. (2020). Pengaruh Teknologi Pembelajaran Kuliah Online di Era Covid19 dan Dampaknya Terhadap Mental Mahasiswa. June. https://doi.org/10.37859/eduteach.v1i2.198 7

Mardesci, H. (2020). Pengaruh Perkuliahan dengan Metode dalam Jaringan (Daring) terhadap Minat Belajar Mahasiswa (Studi Kasus pada Program Studi Teknologi Pangan Universitas Islam Indragiri ). 4(3), 357365.

Marpaung, E. W. B. H., Adrian, L., \& Putri, S. A. (2020). Pandemi COVID-19: Dampak Sosial-Ekonomi, Tantangan, dan Potensi Solusi. Demografi Sosial, May, 1-16. https://doi.org/10.13140/RG.2.2.35252.684 83

Oktavian, R., Aldya, R. F., Indonesia, U. K., \& Tunggadewi, U. T. (2020). Efektifitas Pembelajaran Daring Terintegrasi di Era Pendidikan 4.0. 20(2), 129-135.

Oktawirawan, D. H. (2020). Faktor Pemicu Kecemasan Siswa dalam Melakukan Pembelajaran Daring di Masa Pandemi Covid-19. 20(2), 541-544. https://doi.org/10.33087/jiubj.v20i2.932

Pangondian, R. A., Santosa, P. I., \& Nugroho, E. (2019). Faktor - Faktor Yang Mempengaruhi Kesuksesan Pembelajaran Daring. 56-60.

PDSKJI. (2020). Masalah Psikologis Di Era Pandemi Covid-19. Pdskji.Org

Pratiwi, E. W. (2020). Dampak Covid-19 Terhadap Kegiatan Pembelajaran Online di
Sebuah Perguruan Tinggi Kristen di Indonesia. https://doi.org/doi.org/10.21009/PIP.341.1

Purwanto, Ngalim. 2004. Psikologi Pendidikan. Jakarta. PT. Remaja Rosdakarya

Sadikin, A., \& Hamidah, A. (2020). Pembelajaran Daring di Tengah Wabah Covid-19. Biodik, 6(2), 109-119. https://doi.org/10.22437/bio.v6i2.9759

Utami, D. S. (2020). Pedoman Dukungan Kesahatan Jiwa dan Psikososial pada Pandemi Covid-19. Direktorat Jendral Pencegahan dan Pengendalian Penyakit Kementrian Kesehatan RI.

Uyun, M., Psikologi, F., Islam, U., Raden, N., \& Palembang, F. (2020). Peran Psikolog dalam Bidang Pendidikan, Pemerintahan dan Industri. 7, 61-78. https://doi.org/10.15575/psy.v7i1.6349

Zhafira, N. H., Ertika, Y., \& Chairiyaton. (2020). Persepsi Mahasiswa Terhadap Perkuliahan Daring Sebagai Sarana Pembelajaran Selama Masa Karantina Covid-19. Jurnal Bisnis Dan Kajian Strategi Manajemen, 4(1), 37-45. 